\title{
NEED ASSESSMENT PESERTA PROGRAM PELATIHAN PENDIDIKAN ANAK USIA DINI KECAMATAN CILEUNGSI
}

\author{
WIDIA WINATA \\ Universitas Muhammadiyah Jakarta (UMJ) \\ Jl. KH. Ahmad Dahlan Cirendeu, Ciputat, 15419 \\ Tlp/Fax: 0217442028/0217442330 Email: widiakamek@ gmail.com
}

\begin{abstract}
The purpose of this study was to determine the needs (need assessment) participants and the training of Early Childhood Education (ECE) in the area of Cileungsi, Bogor. Qualitative descriptive study took the data with techniques of observation, interviews, documentation and questionnaires were distributed to 25 participants of seminars and training ECE group representatives throughout Cileungsi. The research found as many as 14 people who chose the topic of learning methods with sources of early childhood practitioners. Training model which is expected to be sustainable and the dominant practice. This study is the realization of the course education training program studi early childhood students in tier 1 study program teacher education ECE Universitas Muhammadiyah Jakarta.
\end{abstract}

Keywords: need assessment, training program, early childhood education

\begin{abstract}
Abstrak : Tujuan penelitian ini adalah untuk mengetahui kebutuhan (need assessment) peserta seminar dan pelatihan Pendidikan Anak Usia Dini (PAUD) di wilayah Cileungsi, Bogor. Penelitian yang bersifat kualitatif deskriptif ini mengambil data dengan teknik pengamatan, wawancara, dokumentasi dan angket yang disebar kepada 25 peserta seminar dan pelatihan PAUD perwakilan gugus PAUD se-Cileungsi. Hasil penelitian ditemukan sebanyak 14 orang yang memilih topik metode pembelajaran dengan narasumber praktisi PAUD. Model pelatihan yang diharapkan harus berkesinambungan dan dominan praktek. Penelitian ini merupakan realisasi dari mata kuliah Pendidikan Program Pelatihan PAUD yang dipelajari mahasiswa di Program Studi Strata 1 Pendidikan Guru PAUD Universitas Muhammadiyah Jakarta.
\end{abstract}

Kata kunci: need assessment, program pelatihan, pendidikan anak usia dini

Pelaksanaan pendidikan di

Indonesia dirangkai dalam aturan yang baku dalam Undang-Undang nomor 20 tahun 2003 pasal 3 tentang

Sistem Pendidikan Nasional. Pendidikan nasional berfungsi mengembangkan kemampuan dan membentuk watak serta peradaban bangsa yang bermartabat dalam rangka mencerdaskan kehidupan bangsa, bertujuan untuk berkembangnya potensi peserta didik agar menjadi manusia yang beriman dan bertakwa kepada Tuhan Yang Maha Esa, berakhlak mulia, sehat, berilmu, cakap, kreatif, mandiri dan 
menjadi warga negara yang demokratis serta bertanggung jawab (Undang-Undang Sistem Pendidikan Nasional, 2003: 7). Pengembangan kemampuan peserta didik tersebut dilakukan oleh pendidik yang berkualifikasi sebagai guru, dosen, konselor, pamong belajar, widyaiswara, tutor, instruktur, fasilitator, dan sebutan lain yang sesuai dengan kekhususannya serta berpartisipasi dalam menyelenggarakan pendidikan (Undang-Undang Sistem Pendidikan Nasional, 2003: 7).

Pendidik di tingkat Pendidikan Anak Usia Dini (PAUD) tidak seperti di tingkat sekolah lanjutan seperti Sekolah Dasar (SD). Mereka masih banyak yang belum mengenyam pendidikan sarjana PAUD sesuai dengan tuntutan profesinya. Ella Yulaelawati, Direktur Pembinaan PAUD Direktorat Jenderal Pendidikan Anak Usia Dini dan Pendidikan Masyarakat (Ditjen PAUDNI-

Dikmas) Kemdikbud mengatakan bahwa jumlah tenaga kependidikan PAUD tahun 2015 sebanyak 588.475. Di antara mereka, 66\% belum memiliki ijazah Sarjana (S1) (Berita Satu, 2015). Imbas dari kenyataan ini membuat guru TK mengajar sesuai dengan pengalaman dan kemampuannya dengan minim pengetahuan tentang ke-PAUD-an. Hal ini diiyakan oleh mantan Rektor Universitas Negeri Jakarta (UNJ), Bedjo Sujanto bahwa di lingkup Rukun Warga (RW) banyak sekali pendidik PAUD yang masih berpendidikan Sekolah Menengah Atas (SMA). Bagi mereka yang lulusan SMA ini diberikan kesempatan untuk mengikuti pelatihan PAUD selama waktu tertentu agar memiliki kemampuan mendampingi psikologis anak didiknya. Setelah pelatihan mereka akan diberikan sertifikat pelatihan PAUD oleh UNJ yang notabene memiliki program S1 PAUD di Fakultas Ilmu Pendidikannya (Zubaidah, 2015).

Kesempatan memperoleh pelatihan dari UNJ tentu bukan perkara mudah apalagi bagi pendidik PAUD yang berasal dari daerah. Pendidik PAUD di Kecamatan Cileungsi, Kabupten Bogor misalnya, jarak tempuh mereka ke 
Need Assesment . . .

Widia Winata

Jakarta cukup jauh, belum lagi persoalan dana transportasi dan biaya pelatihan di sana. Mengantisipasi persoalan ini maka mereka mengikuti pelatihan-pelatihan yang diadakan di wilayahnya seperti yang dilaksanakan oleh Himpunan Pendidik dan Tenaga Kependidikan Anak Usia Dini Indonesia (HIMPAUDI) wilayah Cileungsi pada tanggal 20 Agustus 2015 lalu. Narasumber pelatihan yang bertema Aplikasi Kurikulum 2013 PAUD, Sholehah mengatakan bahwa di antara peserta yang berjumlah 34 orang yang mengikuti pelatihan itu hanya tiga orang saja yang pernah mengenal Kurikulum 2013 PAUD. Mereka yang bertiga itu pernah mengikuti pelatihan singkat di Bogor beberapa bulan lalu (Hasil wawancara tak terstruktur).

$$
\text { Walaupun pelatihan }
$$

dilaksanakan, namun narasumber lebih banyak berceramah tanpa adanya praktek langsung. Peserta hanya duduk di kursi masing-masing mendengarkan materi, sementara pelatihan seharusnya memuat unsur latihan dan praktek-praktek yang harus diikuti para peserta. Peneliti melihat pemahaman terhadap konsep pelatihan dan seminar belum begitu dimengerti oleh panitia dan narasumber saat itu. Bahkan peserta mengeluhkan kebosanan saat mengikuti acara karena materi Kurikulum 2013 PAUD hanya ditampilkan dalam bentuk slide-slide berupa cuplikan-cuplikan saja (Hasil wawancara tak terstruktur). Acara yang dilakukan tanggal 20 Agustus 2015 layaknya disebut dengan seminar.

Pemahaman tentang konsep seminar dan pelatihan dipelajari oleh mahasiswa semester tujuh Program Studi PAUD Fakultas Ilmu Pendidikan (FIP) Universitas Muhammadiyah Jakarta (UMJ) dalam mata kuliah Program Pelatihan PAUD yang memuat 3 sks dalam satu semester (Jadwal Perkuliahan Semester Ganjil 2015/2016). Sejak tiga tahun terakhir peneliti menjadi dosen pengampu mata kuliah tersebut. Luaran mata kuliah Program Pelatihan PAUD mengharuskan mahasiswa mengadakan evens yang berkaitan dengan topik-topik PAUD. Evens tersebut seperti seminar, pelatihan, 
JURNAL PENDIDIKAN USIA DINI

Volume 10 Edisi 2, November 2016

simposium, talkshow, Focus Group

Discussions (FGD) atau ceramah ilmiah.

Permasalahnnya, sudah dua tahun berturut-turut (2013 dan 2014) seminar yang diadakan selalu mengetengahkan tema yang sama. Apa yang dipikirkan oleh mahasiswa sebagai kebutuhan masyarakat PAUD ternyata pada saat pelaksanaan tidak sepenuhnya demikian. Topik Sex Education kembali terulang sehingga menimbulkan kebosanan dan berkurangnya minat peserta pada tahun berikutnya (Jadwal Perkuliahan Semester Ganjil 2015/2016). Mengantisipasi hal ini peneliti berpikir, bagaimana kalau diadakan penelitian untuk melihat dan menemukan apa saja topik yang dibutuhkan stakeholder PAUD saat ini, khususnya pendidik di lembaga formal dan nonformal. Penilaian kebutuhan (need assessment) ini diasumsikan dapat menentukan

\section{Pengertian Need Assessment}

Need assessment berasal dari bahasa Inggris yang terdiri dari dua kata; need yang berarti kebutuhan, kebutuhan yang sesuai dengan minat masyarakat PAUD, baik dari sisi topik, narasumber maupun hal lainnya yang terkait dengan pelaksanaan pelatihan tersebut sehingga tidak terjadi lagi overlapping tema di acara tersebut.

Berdasarkan latar belakang yang diungkapkan, masalah yang menjadi pokok dalam penelitian ini difokuskan pada kondisi penilaian kebutuhan (need assessment) peserta Program Pelatihan PAUD yang ada di wilayah Kecamatan Cileungsi. Rumusan masalah yang dibuat mencakup, bagaimana kondisi peserta Program Pelatihan PAUD yang ada di wilayah Kecamatan Cileungsi? Topik apa saja yang dibutuhkan oleh peserta Program Pelatihan PAUD yang ada di wilayah Kecamatan Cileungsi? Narasumber yang bagaimana yang sesuai dengan kebutuhan peserta Program Pelatihan PAUD yang ada di wilayah Kecamatan Cileungsi?

keperluan dan assessment yang berarti penilaian, penaksiran (Echol, 1996: 41, 392). Jika digabungkan menjadi satu maka need assessment 
Need Assesment . . .

Widia Winata

berarti penilaian kebutuhan. berkembang sesuai dengan Penilaian kebutuhan yang kebutuhan dan kodisi peserta didik. dimaksudkan di sini adalah penilaian Pengertian yang hampir serupa kebutuhan peserta Program Pelatihan dikatakan oleh Djaali dan Muljono PAUD.

Menurut Goodwin and Goodwin, assessment adalah proses penentuan suatu kondisi dengan menggunakan teknik seperti pengamatan, wawancara, angket, tes atau skor (Wortham, 2011: 3). Teknik pengamatan, tes atau skor menjadi alat bantu dalam menentukan atau menilai suatu kondisi yang dihadapi. Assessment mulai dikenal dalam dunia pendidikan sejak Alfred Binet membuat skor pada tes kecerdasan seorang individu. Skor itu membantu dalam pengambilan keputusan pada posisi atau level mana kecerdasan seseorang berada.

Assessment merujuk pada kumpulan informasi yang relevan untuk membantu individu dalam mengambil keputusan (Tylor, 2006: 3). Pengertian ini diadobsi oleh dunia pendidikan untuk merealisasikan strategi pembelajaran yang cocok bagi peserta didik. Assessment bersifat dinamis dan selalu bahwa assessment berarti menilai sesuatu yakni mengambil keputusan terhadap sesuatu dengan mengacu pada ukuran tertentu seperti menilai baik atau buruk, tinggi atau rendah (Djaali, 2008: 2).

Berdasarkan paparan di atas dapat disimpulkan bahwa need assessment adalah penilaian kebutuhan peserta Program Pelatihan PAUD yang mengacu pada kondisi tertentu dengan menggunakan teknik pengamatan, wawancara dan angket.

\section{Prinsip Need Assessment}

Pelaksanaan penilaian harus memperhatikan prinsip-prinsip yang ada (Wortham, 2011: 3). Prinsip need assessment tersebut $\mathrm{di}$ antaranya adalah:

1) Assessment menggunakan sumber informasi yang beragam Informasi yang dikumpulkan untuk keperluan assessment berasal dari sumber yang beragam bukan hanya satu sumber saja. Penggunaan lembar 
pengamatan bisa ditambahkan dengan wawancara atau rubrik yang dapat memperkaya penilaian.

2) Bersifat autentik

Apa yang menjadi dasar penilaian harus yang sebenarnya terjadi tidak bisa direkayasa. Objektivitas sangat diperlukan agar hasil assessment menjadi original.

3) Bertujuan untuk meningkatkan suatu kondisi

Jika digunakan untuk proses pembelajaran maka tujuan assessment salah satunya adalah guna meningkatkan kondisi pembelajaran agar menjadi lebih baik. Jika digunakan untuk

Mata Kuliah Pendidikan Program Pelatihan PAUD

Pendidikan

Program

Pelatihan PAUD menjadi salah satu mata kuliah yang diajarkan kepada mahasiswa calon pendidik anak usia dini di jenjang S1 (Kumpulan Silabus Program Studi PGPAUD FIP UMJ). Mata kuliah ini disediakan pada semester tujuh saat mahasiswa sudah hampir menyelesaikan semua kepentingan need assessment peserta Program Pelatihan PAUD maka tujuannya adalah untuk memperbaiki proses pelatihan yang akan diikuti di masa yang akan datang baik dari segi topik yang akan dipilih panitia, narasumber maupun teknis pelaksanaan lainnya.

4) Adil dan merata Assessment berlaku untuk semua individu tidak hanya sebagian karena alasan-alasan tertentu (Wortham, 2011: 3). Need assessment berlaku untuk semua peserta Program Pelatihan PAUD tanpa terkecuali dengan kreteria yang sudah ditentukan.

perkuliahan. Diletakkannya mata kuliah ini pada semester akhir menjelang skripsi dengan maksud bahwa mahasiswa sudah memiliki dasar mata kuliah lain khususnya konsep dasar PAUD. Dasar itu kemudian dijadikan sebagai bahan pertimbangan dalam memilih topik apa yang akan diangkat dalam pelaksanaan Program Pelatihan 
Need Assesment . . .

Widia Winata

PAUD di akhir pertemuan operasional kegiatan termasuk biaya perkuliahan tersebut.

Perkuliahan Pendidikan honor narasumber yang diundang.

Bentuk Pendidikan Program Program Pelatihan PAUD terdiri dari 16 kali tatap muka yang divariasikan (Berita Acara Perkuliahan dan Daftar Hadir). Sebagian pada awal semester dan sebagaian lagi di tengah semester. Biasanya pertemuanpertemuan itu dibuat sedemikian rupa sehingga tidak selalu menggunakan metode ceramah dalam proses pembelajarannya. Dosen lebih banyak mendisain metode diskusi dan melihat problem yang terjadi dalam masyarakat khususnya permasalahan yang terkait dengan pendidikan dan tumbuh kembang anak usia dini.

\section{Pertengahan semester,}

mahasiswa sudah mulai membuat proposal kegiatan dan mencari sponsor yang akan mambantu mendanai kegiatan. Seringkali karena berbagai faktor, sponsor tidak ditemukan lalu pembiayaan pelatihan dilimpahkan kepada peserta sepenuhnya dengan cara peserta membayar dengan sejumlah uang. Uang itu kemudian digunakan untuk Pelatihan PAUD yang dilaksanakan ada beberapa macam, di antaranya dalam bentuk pelatihan, seminar, parenting, simposium, talkshow, FGD dan ceramah agama atau ceramah ilmiah (Skb, 2015). Ceramah ilmiah dapat disamakan dengan kuliah umum yang diperuntukkan bagi mahasiswa semester awal. Dari semua bentuk Program Pelatihan PAUD tersebut, mahasiswa yang mengikuti kuliah ini memilih secara bermusyawarah bentuk mana yang akan dilaksanakan pada akhir pertemuan kuliah. Pelaksanaan Program Pelatihan PAUD dinilai oleh dosen sebagai tugas akhir dan dimasukkan ke dalam kategori Ujian Akhir Semester (UAS).

Kegiatan yang telah dilaksanakan dibuat laporannya untuk arsip penilaian dosen dan untuk arsip di Program Studi PGPAUD FIP UMJ. Laporan ini bernilai sebagai bukti kegiatan mahasiswa dan dosen yang dapat pula dijadikan lampiran dalam 
borang akreditasi Program Studi PGPAUD, FIP maupun akreditasi institusi UMJ. Laporan tersebut kemudian dievaluasi apakah ada kelemahan yang harus diperbaiki dosen dan mahasiswa di semester berikut saat perkuliahan Pendidikan Program Pelatihan PAUD tahun mendatang atau ada kekuatan pelaksanaan kegiatan yang harus dipertahankan. Penelitian internal

\section{Hasil Penelitian Sebelumnya}

Penelitian yang relevan dilakukan oleh Shallcross dari Manchester Metropolitan University, UK (Shallcross, 2003: 3). Ia membuat program pelatihan kepada guru-guru dengan model Education for Sustainable Development (ESD) dalam rangka menjawab tuntutan perkembangan dalam dunia Jurnal yang sama juga menjelaskan hasil penelitian tentang pelatihan yang dilakukan terhadap guru guna peningkatan kualitas dan kompetensi guru di Estonia. Poom dan rekan-rekannya menjelaskan bahwa sejak 2001 pemerintah setempat telah meluncurkan
UMJ yang didanai oleh pihak rektorat UMJ ini adalah salah satu bentuk evaluasi program agar pelaksanaan Program Pelatihan PAUD selanjutnya yang dilaksanakan Desember 2016 dan Januari 2017 bisa berjalan dengan baik dan tepat sasaran sesuai dengan penilaian kebutuhan (need assessment) peserta Program Pelatihan PAUD.

pendidikan di wilayahnya. Model ini menekankan pada kolaborasi budaya setempat dengan praktek pendidikan di sekolah. Guru juga seharusnya rasional untuk menghubungkan antara teori dengan praktek dalam akademk. Shallcross mengadakan pelatihan kepada guru-guru agar konsep ini terlaksana dengan baik (Shallcross, 2003: 3). kurikulum baru namun ternyata masih banyak guru yang belum memahaminya. Oleh karena itu perlu dilakukan pelatihan agar kurikulum tersebut terealisasikan dengan baik dan merata di semua jenjang pendidikan. Model pendidikan dan pelatihan guru yang dilakukan di 
Need Assesment . . .

Widia Winata

Estonia terdiri dari dua macam yakni model yang terintegrasi seperti yang dilakukan di prasekolah dan model yang tidak terintegrasi seperti sekolah lanjutan yang menggunakan mata pelajaran terpisah. Data yang disampaikan Poom memperlihatkan $27,8 \%$ saja guru prasekolah atau PAUD yang mengenyam pendidikan

Penelitian yang relevan lainnya dilakukan oleh Woodward. Ia menganjurkan para guru agar terus berlatih menulis karena menulis merupakan keahlian yang tidak bisa datang begitu saja tetapi harus terus dilatih. Menulis juga dapat menunjang bagaimana seorang guru menyampaikan hasil penelitiannya

\section{TUJUAN PENELITIAN}

Tujuan penelitian ini adalah untuk menemukan penilaian kebutuhan (need assessment) peserta Program Pelatihan PAUD yang ada di wilayah Kecamatan Cileungsi, baik dari segi topik yang dibutuhkan, narasumber maupun kondisi umum yang mereka alami. Urgensi penelitian ini agar dosen, mahasiswa, stakeholder PAUD dapat terbantu di perguruan tinggi (Shallcross, 2003: 3). Artinya masih banyak guru yang belum mendapatkan kesempatan belajar tentang Early Childhood Education dan mereka butuh pelatihan di luar sistem pendidikan kampus tersebut (Shallcross, 2003: 3).

secara baik dan rasional karena penelitian merupakan tugas pokok yang dilakukan setiap waktu maka kemampuan guru dalam menulis itu juga harus bagus. Korelasi antara kemampuan menulis yang baik akan menghasilkan publikasi hasil penelitian yang bagus pula (Woodward, 2015).

dalam menemukan kebutuhan mereka; ilmu apa yang akan mereka dalami dalam pelatihan PAUD. Mengingat luasnya cakupan bahasan PAUD dan beragamnya kepentingan masyarakat PAUD saat ini yang semakin berkembang. Tujuan lain adalah terlaksananya luaran mata kuliah Pendidikan Program Pelatihan PAUD yang berkualitas dan tepat sasaran sehingga bisa menjadi ajang 
Need Assesment . . .

Widia Winata

promosi bagi FIP dan UMJ

masyarakat PAUD untuk mencari umumnya, sehingga lembaga informasi PAUD yang terkini dan kampus ini bisa dijadikan referensi berkualitas.

\section{METODE PENELITIAN}

Penelitian ini dilaksanakan di Kecamatan Cileungsi yakni Gugus PAUD yang ada di sana, baik PAUD formal maupun nonformal. Pemilihan tempat karena wilayah ini sangat memerlukan perhatian dalam pelaksanaan Program Pelatihan PAUD baik dari pemerintah, swasta maupun perguruan tinggi yang berkerjasama. Waktu penelitian dilaksanakan selama satu semester yakni Agustus 2015-Januari 2016 selama proses perkuliahan Mata Kuliah Pendidikan Program Pelatihan PAUD berlangsung. Hasil penelitian ini menjadi acuan bagi pemilihan topik apa yang akan dilatihkan atau diseminarkan jika nanti mahasiswa sudah mengakhiri pertemuan-pertemuan perkuliahan ini.

Penelitian ini menggunakan metode kualitatif deskriptif dengan makna prosedur penelitian yang menghasilkan data-data deskriptif berupa kata-kata tertulis atau lisan

dari orang-orang dan perilaku yang dapat diamati (Moleong, 2004: 4). Prosedur penelitiannya mengikuti langkah sebagai berikut (Moleong, 2004: 4):

a. Persiapan penelitian

Pra lapangan dilakukan dengan menyusun rancangan penelitian dan mempersiapkan peralatan yang diperlukan. Rumusan masalah disusun, menentukan lokasi penelitian dan mengurus permohonan izin kepada pihak terkait seperti HIMPAUDI Kecamatan Cileungsi. Peneliti kemudian menjajaki dan menilai lapangan untuk memilih dan memanfaatkan informan dalam mendapatkan data yang dimaksudkan.

b. Pelaksanaan penelitian

Memasuki lapangan dengan mendatangi acara pelatihan atau seminar yang diadakan oleh HIMPAUDI Kecamatan Cileungsi atau perguruan tinggi yang bekerjasama dengan pendidik di 
Need Assesment . . .

Widia Winata

Gugus Kecamatan Cileungsi. Cileungsi. Mereka adalah para Mengamati proses yang pendidik PAUD yang tersebar di berlangsung, melakukan Gugus Kecamatan Cileungsi dengan wawancara dan menyebarkan jumlah 25 orang peserta yang angket kepada peserta. Peneliti mewakili lembaga PAUD setempat. juga turut berperan serta dalam Data yang dimaksud bersifat acara tersebut sambil mengumpulkan data agar lebih mendalami kondisi peserta Program Pelatihan PAUD.

c. Pelaporan hasil penelitian

Peneliti melakukan analisis data kualitatif dan interpretasi data. Analisis data mengacu pada model perbandingan tetap (constant comparative method) yang dipopulerkan oleh Glaser and Strauss (Moleong, 2004: 287). Hasil analisis data kemudian diinterpretasikan dan dilakukan triangulasi data untuk memperkuat data-data yang telah ada. Setelah selesai barulah peneliti menulis laporan yang akan disampaikan ke lembaga penelitian kampus (LPPM) serta mempublikasikan secara ilmiah.

Data yang diperoleh dalam penelitian ini bersumber dari para peserta Program Pelatihan PAUD yang diadakan di Kecamatan kualitatif yang didapatkan dari katakata dan tindakan para peserta yang dicatat melalui catatan tertulis atau perekaman video/foto. Data tambahan berupa dokumentasi yang diperlukan dan data statistik. Peneliti berperan sebagai instrumen penelitian dengan ikut berperan serta dalam kegiatan Program Pelatihan PAUD. Proses pengumpulan data dilakukan dengan pengamatan berperan serta langsung, wawancara terstruktur dan tidak terstruktur serta dukungan dokumentasi. Data-data tersebut diperiksa keabsahan datanya dengan menggunakan teknik perpanjangan keikutsertaan, ketekunan pengamatan dan triangulasi.

Peneliti melakukan analisis data kualitatif dan interpretasi data. Analisis data mengacu pada model perbandingan tetap (constant comparative method) yang dipopulerkan oleh Glaser and Strauss 
JURNAL PENDIDIKAN USIA DINI

Volume 10 Edisi 2, November 2016

(Moleong, 2004: 287). Alasan dengan kategori yang lainnya. Proses pemilihan model ini karena peneliti analisis data ini mengikuti prosedur; membandingkan satu data dengan reduksi data, kategorisasi data, data yang lainnya kemudian sintesisasi dan menyusun hipotesis membandingkan satu kategori kerja.

Bagan penelitian menggambarkan alur penelitian yang dapat dilihat sebagai berikut:

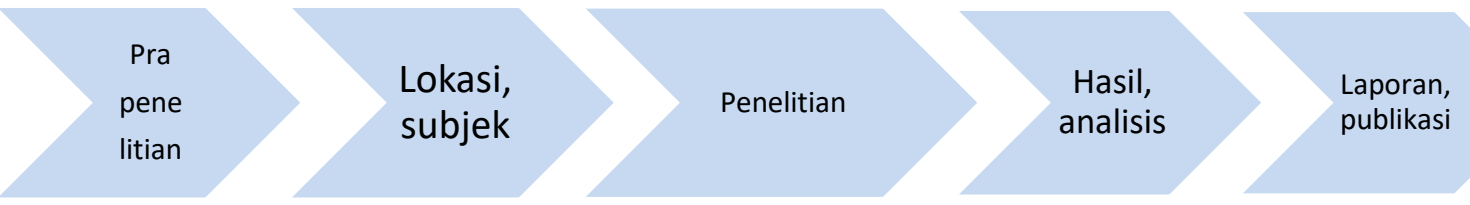

\section{Gambar 1.Bagan Penelitian}

Langkah awal yang dilakukan adalah melaksanakan prapenelitian dengan meninjau lokasi. Peneliti menelaah apa yang sebenarnya menjadi ketertarikan dalam kajian. Melihat permasalahan apa yang terjadi disertai dengan membaca berbagai referensi yang terkait dengan topik. Semua referensi dikelompokkan sesuai dengan aspek yang akan diteliti.
Setelah ditentukan lokasi dan subjek yang dimaksud, yakni Kecamatan Cileungsi dengan subjek peserta Program Pelatihan PAUD maka peneliti merancang langkah penelitian sesuai jadwal, analisis data dan menuliskan hasil laporan serta mempublikasikan hasil penelitian tersebut. 
Need Assesment . . .

Widia Winata

HASIL DAN PEMBAHASAN

Data yang dihasilkan dalam penelitian ini berasal dari hasil pengamatan, wawancara dan angket dengan format yang dibatasi pada pertanyaan inti. Pada saat wawancara, pertanyaan diberikan secara tidak terstruktur untuk menjaring jawaban yang lebih terbuka dan triangulasi data. Subjek penelitian dapat pula menambahkan kritik dan saran setelah mereka mengisi angket.
Berdasarkan data yang diperoleh, terlihat bahwa peserta seminar atau pelatihan PAUD memilih untuk memperdalam pengetahuan dan aplikasinya tentang metode atau bagaimana cara/teknik mengajar. Aspek ini kemudian ditunjang oleh keinginan untuk mendapatkan informasi dan aplikasi dari pendidik atau praktisi PAUD. Dari 25 peserta, 14 orang memilih topik dan narasumber tersebut. Hal ini dapat digambarkan dalam grafik di bawah ini:

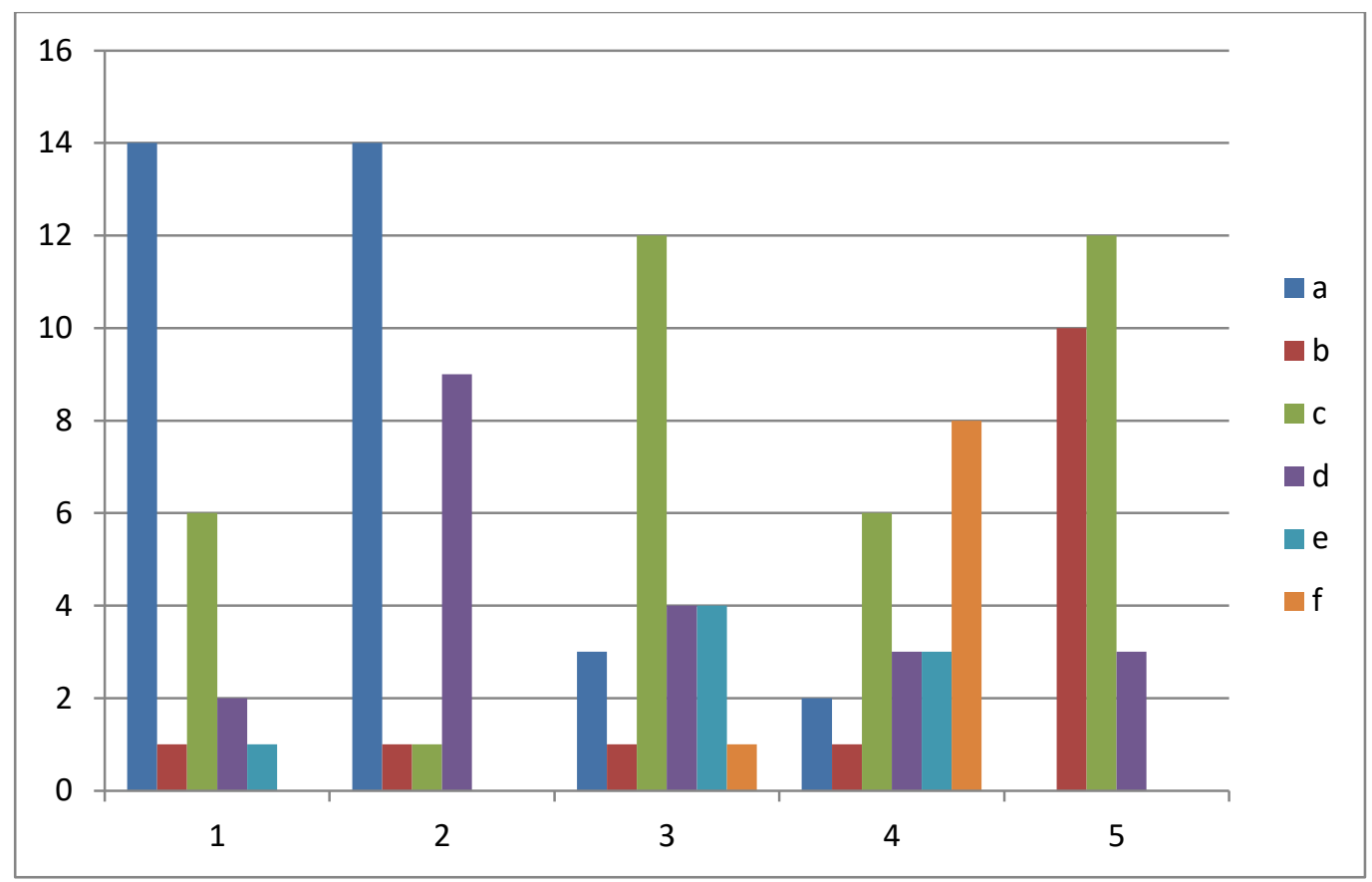

Grafik 1. Perolehan Need Assessment Peserta Pelatihan PAUD 
Pemilihan topik aplikasi kurikulum menjadi pilihan kedua terbanyak peserta. Hal ini juga dikaitkan dengan munculnya kurikulum baru yakni Kurikulum 2013 PAUD yang sebagian lembaga PAUD sudah menjalankannya.

Hasil wawancara yang peneliti dapatkan, umumnya proses belajar mengajar di PAUD lebih menekankan pada aspek calistung (membaca, menulis dan berhitung). Metode yang digunakan belum bervariasi. Padahal banyak metode yang bisa digunakan seperti cerita, bermain peran, bernyanyi, teladan, perumpamaan, eksperimen, demonstrasi dan karyawisata. Hal ini diperkuat dengan catatan yang ditulis peserta dalam kotak saran dan kritikan. Mereka merasa belum maksimal dalam menerapkan metode yang ada selama ini. Umumnya mereka menginginkan diadakan lagi pelatihan secara berkala dan berkesinambungan baik dari pemerintah daerah atau kerjasama dengan perguruan tinggi.

Narasumber yang diinginkan adalah pendidik PAUD atau bahasa lainnya adalah praktisi PAUD. Alasan mereka memilih tokoh ini karena merekalah yang menghadapi anak setiap hari dan memahami kondisi anak secara real. Hanya satu orang saja yang memilih pemangku kebijakan karena menurut mereka seringkali pemangku kebijakan justru tidak memahami bagaimana kondisi anak di lapangan. Jadi lebih baik memilih praktisi yang sudah berpengalaman langsung.

Mengenai waktu pelaksanaan seminar/pelatihan, peserta menginginkan mulai dari pukul 08.00 WIB sampai 16.00 WIB on time di hari Sabtu. Pembahasan juga langsung pada pokok tema tidak berbelit-belit dan tidak hanya pada tataran teoritis belaka. Kajian juga melibatkan peserta sehingga suasana tidak membosankan dan mereka bisa berperan aktif dalam kegiatan seminar/pelatihan. Agar kegiatan fokus maka peserta yang terlibat berkisar antara 30-50 orang yang mengikutsertakan guru kelas dan kepala PAUD. Masing-masing kegiatan diberi jedah waktu untuk 
Need Assesment ...

Widia Winata

melaksanakan game edukatif agar

acara semakin menarik.

\section{SIMPULAN}

Berdasarkan paparan dalam
hasil penelitian maka dapat
disimpulkan bahwa kondisi peserta
program pelatihan PAUD di wilayah
Cileungsi masih membutuhkan
perhatian untuk mendapatkan
berbagai informasi dan pengetahuan
ilmu ke-PAUD-an. Ini ditandai
dengan pernyataan mereka bahwa
masih membutuhkan banyak
kesempatan untuk mengikuti latihan yang bersifat berkesinambungan. Peserta juga menginginkan agar topik yang disajikan dalam kegiatan pelatihan berikutnya adalah materi tentang metode pembelajaran PAUD yang dirasa masih belum maksimal dilaksanakan dalam kelas-kelas PAUD selama ini. Topik tersebut disampaikan oleh para narasumber yang memiliki reputasi sebagai praktisi yang berpengalaman di bidangnya. Dengan demikian apa yang disampaikannya merupakan hal yang benar-benar dialami dalam praktek kesehariannya.
Implikasi dari penelitian ini memberikan gambaran bagi mahasiswa PAUD di Prodi PGPAUD FIP UMJ untuk mengadakan pelatihan PAUD dengan materi metode pembelajaran dengan narasumber praktisi PAUD. Di saat pelaksanaan ujian akhir semester mata kuliah Program Pelatihan PAUD kesimpulan penelitian ini dapat menjadi pedoman pelaksanaan pelatihan berikutnya.

$$
\text { Saran bagi dosen dan }
$$
mahasiswa yang mengikuti mata kuliah ini harus menjadikan suara peserta ini sebagai acuan karena permasalahan PAUD berasal dari mereka sebagai orang lapangan. Sinergi antara akademisi menjadi terintegrasi dengan kebutuhan masyarakat PAUD pada umumnya. Selanjutnya hasil penelitian ini dapat menjadi referensi agar bisa dilakukan penelitian selanjutnya dalam bidang pelatihan khususnya bidang PAUD. 


\section{DAFTAR PUSTAKA}

Berita Satu. 2015. Sebagian Besar Guru PAUD Belum Sarjana. www.m.beritasatu.com, (diakses 30 Nopember 2015)

Djaali dan Pudji Muljono. 2008. Pengukuran dalam Pendidikan. Jakarta: Gramedia

Echols, John M. and Hassan Shadily. 1996. Kamus Inggris-Indonesia. Jakarta: Gramedia

Moleong, Lexy J. 2004. Metodologi Penelitian Kualitatif. Bandung: Remaja Rosdakarya

Shallcross, Tony. 2003. Cultural Lessons About Educational for Sustainable Development and Teacher Education from Europian Project. Journal of Teacher Education and Training, Volume 3. 2003. www.iselv.eu/ufiles, (diakses 23 Agustus 2015)

Skb, Asolihin. Pengertian dan JenisJenis Program Parenting. www.paud-

anakbermainbelajar.blogspot.co

$\mathrm{m}$

Taylor, Ronald L. 2006. Assessment of Exceptional Students; Educational and Psychological Procedures. Boston: Pearson

-----, $\quad$ Undang-Undang tentang Sistem Pendidikan Nasional tahun 2003. 2003. Jakarta: Tamita Utama

Wortham, Sue. 2001. Assessment in Early Childhood Education. Ohio: Merril Prentice Hall

Woodward, Tessa. 2015. Teachers as Writers: Writing Your Way to Professional Development. Journal of The Teacher Trainer, Volume 29 no 2, July 2015. www.tttjournal.co.uk, (diakses 20 Agustus 2015)

Zubaidah, Neneng, 2014. 80\% Guru TK Belum S1 atau D4. http://nasional.sindonews.com/re ad/843392, (diakses 22 Agustus 2015) 